\title{
$P-233$ 腎細胞癌におけるシアリルルイスX関連抗原発現の免疫組織化学的検討
}

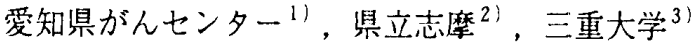

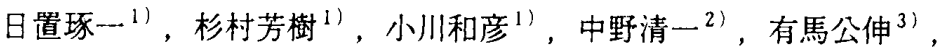 \\ 川村寿一 3 !
}

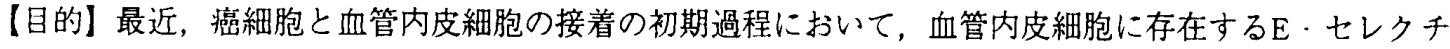
ンと糖鎖抗原シアリルルイスXとの結合が注目されており，大腸癌，膀胱癌ではシアリルルイスXを発 現する癌細胞ほど転移の頻度が高いという報告がみられる．今回我々は，督細胞癌におけるシアリルル イスXを中心とた糖鎖抗原の発現を免疫組織化学的に検討し，臨床所見における転移の出現と比較し た.【対象と方法】対象は手術を施行した腎細胞癌症例 47 例で，摘出した腎のホルマリン固定パラフィ ン切片を用いて $\mathrm{ABC}$ 法による免疫組織染色を施行した。一次抗体として数種の糖鎖構造を有するシアリ ルルイスX関連抗原に対する抗体（CSLEX，SNH3，FH6，2F3）とシアリルルイスA抗体（2D3）を 用いた。【結果】摘出腎の正常部分において，シアリルルイスXは近位尿細管細胞に発現したが，系球 体にはほとんど発現がみられなかった。䉰細胞癌組織に対するシアリルルイスXの陽性率は約 $30 \%$ ，

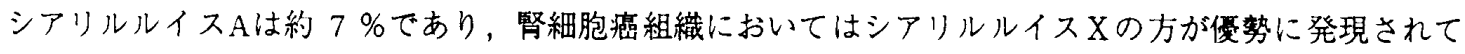
いた。臨床病期では Stage I 32 例中 8 例, Stage II 以上 15 例中 6 例に, 組織学的分化度では grade 1 26 例中 6 例，grade 2 以上 21 例中 8 例において癌細胞にシアリルルイスXの発現を認めたが，臨床病 期, 組織学的分化度との間に関連は認められなかった，遠隔転移の有無，静脈への浸潤の有無，予後と シアリルルイスXの発現の有無に関しても関連は認められなかった，免疫組織化学的検討では，シアリ ルルイスXを発現する腎細胞臨に転移の頻度が高いとは言えなかった。

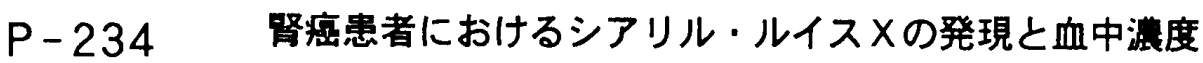

新潟腎癌研究グループ・新潟大学 今井智之, 富田善彦, 斎藤俊弘, 高橋公太

【目的】糖鎖抗原であるシアリル・ルイスX (SLeX) はある種の癌細胞上に発現され，リ ガンドであるセレクチンを介して血管内皮細胞との接着に関与しているとされる．結腸 癌ではその発現と遠隔転移との間に有意な関係を認めており，さらに，血中のSLeX高値 は予後不良因子とされている，今回我々は，腎癌におけるSLeXの意義を調べるため，原 発巣や転移巣におけるSLeXの発現およびその血中濃度と，臨床像との関係を検討した。

【対象と方法】 $-80^{\circ} \mathrm{C} て ゙$ 保存しておいた腎癌患者 150 例の原発巣および 11 例の転移巣（肺 2, 骨2，脳2，皮扂1，対側腎4）に対し，Streptoavidin-biotin bridge techniqueによる免 疫組織学的染色をおこなった。またELISAにて，術前に採取した39例の患者血液中の SLeX濃度を測定した。【結果】免疫組織学的検討では，原発巣150例中47 例 (31.3\%) で，転移巣において11例中6例 (54.5\%) でSLeXの発現を認めた。血中SLeXは，39例中2 例で高値であり，うち1例は多臓器に転移を有する症例であった。【考察】腎癌におい て転移巣にSLeXの発現がより高い頻度で認められ，転移能との関係が推測された。血中 SLeX濃度は上昇例が少なく, 転移との関係ははっきりとしなかった。 